issn: $1808-799 \mathrm{X}$

ano 5 - número 5 - 2007

artigo

\title{
CONCEITUAÇÃO DO TRABALHO NOS MUNDOS DA NECESSIDADE E LIBERDADE,
}

\section{DIREITO E DEVER[1]}

Heitor Coelho[2]

\section{INTRODUÇÃo}

Para muitos daqueles que se dedicam ao estudo da educação, entre os quais me incluo, observar a grande influência do trabalho é lugar-comum. Tal afirmação não objetiva ignorar a discussão acerca do trabalho, seu papel e as diversas formas específicas por meio das quais tal influência se manifesta em diversos campos (e não só o nosso), mas precisamente chamar a atenção para ela; e no campo da educação isto é, talvez, ainda mais válido, pois tentar pensá-lo de maneira mais abrangente é uma luta constante no campo das idéias contra o senso-comum, que pensa a educação ao mesmo tempo como algo limitado num sentido - ocorrendo apenas em certas instituições e momentos - e ilimitado em outro - seu potencial como solução para todos os tipos de problemas sóciopolíticos.

Tal assunto já foi suficientemente abordado por outros autores e não é o tema principal deste artigo; a menção a ele é cabível, porém, por ser uma das premissas de sua redação. De fato, centrar qualquer concepção da educação em momentos tão demasiadamente 
específicos como a escola e a universidade é, sob inúmeros pontos de vista, tão ineficaz para os interessados em sua real melhora quanto conveniente às forças conservadoras[3].

Neste sentido, este artigo pretende colaborar indiretamente para o alargamento e aprofundamento dos estudos no campo da educação em algumas direções: primeiro, optando com mais freqüência, de agora em diante, pelo uso do termo "formação humana", que não partilha de boa parte das já referidas atribuições do senso-comum ao termo "educação"; segundo, revisitando e aprofundando os estudos marxistas sobre a alienação, seus efeitos no mundo do trabalho, na criação de valores, na educação do cidadão; e terceiro, focando a relação entre trabalho, formação humana e Direito, principalmente no papel pedagógico que este adquire ao pressupor a forma alienada de trabalho, garantir a propriedade e obrigar seus "protegidos" à produtividade. Para buscar estes alargamentos, por sua vez, o artigo vale-se daquilo que Lukács considera o mais alto complexo problemático: a questão da necessidade e da liberdade (Lukács, 1978:5), talvez porque, em última instância, seja precisamente nisto que todos estes temas nos interessem naquilo que nos exigem, e naquilo que nos possibilitam.

Comecemos, então, por estes dois últimos, e veremos que o prisma das mediações das categorias da liberdade e da necessidade parece ser o mesmo capaz de gerar as classificações da ordem dos direitos e dos deveres, num plano de legitimidade institucional - o do Direito. Este plano nos mostra uma outra manifestação fenomênica do trabalho, a partir da ordem jurídica instituída, onde o mesmo é modernamente visto como um direito. Vejamos o que diz, por exemplo, a "Declaração Universal dos Direitos do Homem”, em seu artigo 23:

"Toda a pessoa tem direito ao trabalho, à livre escolha do trabalho, a condições eqüitativas e satisfatórias de trabalho e à proteção contra o desemprego.

1.Todos têm direito, sem discriminação alguma, a salário igual por trabalho igual.

2.Quem trabalha tem direito a uma remuneração eqüitativa e satisfatória, que lhe permita e à sua família uma existência conforme com a dignidade humana, e completada, se possível, por todos os outros meios de proteção social.

3.Toda a pessoa tem o direito de fundar com outras pessoas sindicatos e de se filiar em sindicatos para defesa dos seus interesses." (ONU, 2006)

Nossa Constituição possui dispositivo semelhante: 
"Art. $5^{\circ}$ Todos são iguais perante a lei, sem distinção de qualquer natureza, garantindo-se aos brasileiros e aos estrangeiros residentes no País a inviolabilidade do direito à vida, à liberdade, à igualdade, à segurança e à propriedade, nos termos seguintes:

$[\ldots]$

XIII - é livre o exercício de qualquer trabalho, ofício ou profissão, atendidas as qualificações profissionais que a lei estabelecer." (Brasil, 2005)

Ora, os direitos pertencem, aparentemente, ao mundo da liberdade[4], tomando o trabalho como "relação criadora do homem com a natureza" e atendo-se a este aspecto dele. Mas este exemplo mostra, como o sistema que o gerou, alguns sinais que se afastam desta idéia. Nota-se acima, por exemplo, que o mesmo artigo que declara o direito ao trabalho, logo abaixo declara, também, ao emprego e à remuneração justa, ligando necessariamente uma coisa à outra, e aprisionando o trabalho, transformando numa abstração reducionista "o intercâmbio do homem com a natureza [...] em mediações de segunda ordem, onde separa-se o trabalhador dos meios de produção, da cultura criada no ato de produzir, dos objetos produzidos e de sua própria identidade." (Ciavatta, 2002:143)

A idealização tortuosa do direito ao trabalho, num jogo de claro-escuro típico daquilo que Kosik chama de "pseudoconcreticidade", ao mesmo tempo em que busca esconder esta realidade, revela-a (Kosik, 1986:11). Há que se tomar o devido cuidado metodológico com tais elementos, e efetuar distinções: é certo que a capacidade criadora do homem é pertencente ao reino das liberdades e dos direitos, mas, ao atrelar esta atividade a determinadas condições histórico-sociais, será possível que ela verdadeiramente frutifique?

Cabe retomar a questão de outra forma. Deveres existem em diversos graus e formas, mas sempre para com alguma outra pessoa ou entidade. Se o trabalho é um dever, ele é de quem para com quem? Dentro da forma como o trabalho é entendido pelo "senso comum" da comunidade internacional sob as relações sociais capitalistas, a resposta possível será apenas uma: do empregado para com seu empregador.

Assim, a imperatividade do trabalho, sua especificidade, assume caráter contratual, e sua capacidade para realizar a subsistência só pode ser efetivada por meio do dinheiro, fazendo dele necessidade econômica. Nossa investigação da natureza do trabalho como direito e dever, portanto, não pode abster-se desta especificidade histórica, e deverá versar sobre o trabalho como direito e dever dentro do capitalismo contemporâneo 
(também chamado flexível, financeiro, pós-moderno, etc.), focando-se ainda na inserção deste no sistema jurídico brasileiro, e não de maneira pretensamente universal.

De fato, a visão universalizante destes aspectos, isto é, um direito e um dever ao trabalho supra-históricos, ideais, muito comum entre aqueles que os analisam, já é em si um indício da estrutura sob a qual eles se assentam, e parte do processo de disputa de sentido e de poder pelo qual um estado de coisas busca sua própria manutenção e reprodução, pleiteando para si uma suposta "atemporalidade". Embora esta não possa nunca ser plenamente alcançada, a capacidade reprodutora das ideologias "atemporais" não pode ser subestimada, e seu poder chega a ponto de permitir ao Goldstein de Orwell (Orwell, 2006) afirmar que a História não tem uma existência objetiva senão na memória e nos registros do passado, e buscar na construção destes uma permanência dos conceitos (e situações sociais, instituições, etc.) - eternamente insinuada. Ou, dizendo de outra forma, parafraseando o Morfeus de Gaiman (Gaiman, 1995), para sonhar um mundo eterno é necessário sonhá-lo da forma que ele sempre foi, mudar o universo desde o início de tudo até o fim dos tempos; sonho este que muitos já sonharam, voluntária e involuntariamente, visando um bem comum, poder, ou o que quer que fosse. $E$ compreender um presente historicizado, cuja origem reside num passado diverso dele, significa vislumbrar também um futuro diverso, e obter, talvez, elementos para atuar na sua criação.

\section{TRABALHO, LIBERDADE E NECESSIDADE NA TEORIA MARXISTA}

É necessário antes de tudo partir dos pressupostos de que: não há liberdade absoluta; a liberdade deve, como a necessidade, ter um objeto; ela só é possível para um ser determinado e, portanto, limitado; e finalmente, deixar de lado qualquer tipo de liberdade transcendental no sentido metafísico, compreendendo que a transcendência (Aufhebung)[5] de que fala Marx é específica, chegamos a um dos pontos de partida de Mészáros:

“... a verdadeira questão é a liberdade humana, não um princípio abstrato chamado 'liberdade'. E como o caráter específico de tudo é ao mesmo tempo tanto a 'essência' (poder, potencial, função) daquela determinada coisa como o seu limite, assim se verá que a liberdade humana não é a transcendência das limitações (caráter específico) da natureza humana, mas uma coincidência com elas." (Mészáros, 1981:145) 
Isto posto, cabe agora perguntarmo-nos que tipo de liberdade nos interessa, então, analisar, e em relação a quais objetos nos interessa discutir o problema da liberdade e sua relação com a necessidade e o trabalho. Preliminarmente é necessário esclarecer o caráter transcendental da liberdade na literatura marxista, para o que enfrentaremos algumas dificuldades. Em primeiro lugar, há o já mencionado problema de tradução, protagonizado pelo termo Aufhebung, que tem significados mais amplos, e em segundo lugar, é claro que estas afirmações dizem respeito a transcendências diferentes: no caso, nega-se uma transcendência da matéria, da história, e afirma-se a capacidade de transcender outra coisa - a alienação. Esta transcendência ou superação é a chave para compreender a concepção marxista de liberdade também porque, de fato, parece-me evidente que ela é um pré-requisito para o exercício da liberdade.

Mészáros sugere que este problema seja discutido em relação a três objetos, ou grupos de objetos, quando se indagando acerca da influência das formas de propriedade sobre a liberdade. A questão é, para ele, avaliar o quanto o homem está livre: “1) da necessidade [carência] natural[6][7]; 2) do poder de interferência de outros homens; 3) em relação a um exercício mais cabal de seus próprios poderes." (Mészáros, 1981:137)

Embora o autor faça uso específico destes três grupos, creio ser altamente eficaz para nossos propósitos também (se mantivermos em mente que estes três aspectos são inseparáveis, e não podem ser considerados isoladamente).

Por ora, nossa ênfase deve recair sobre o fato de que não podemos considerar nem um, nem outro destes grupos acima, como absolutos; teremos de falar, como Mészáros, sempre em graus de liberdade, pois o homem é parte da natureza e não pode, logicamente, estar totalmente livre dela; assim como, enquanto viver em sociedade, não poderá livrar-se dos demais seres humanos. Neste sentido, é o terceiro tipo que exigirá nossa maior atenção.

Que podemos entender por "liberdade para exercer seus próprios poderes", ou, como o autor também a chama, "liberdade na relação consigo mesmo"? Em Locke, esta relação é mediada pela propriedade do homem sobre si (II. 27 e 28); para Mészáros - e para Marx - é outra coisa: diz respeito ao poder de objetivar-se através do trabalho, exercido como atividade livre[8], e tornar-se um ser universal, livre (Mészáros, 1981:141). Isto só é possível, diz Marx, quando o homem relaciona-se consigo mesmo "como com um ser universal, e por isso livre" (Marx, 2004:83-84); em outras palavras, quando o indivíduo considera tanto a si mesmo como parte do gênero humano, como este gênero o de seres livres.

A própria idéia da relação do homem consigo como propriedade, quer de si como de outro, já é exemplo de um freio a este tipo de liberdade. Mas o estudo específico, tanto das formas de liberdade como de sujeição em relação aos três grupos, exige o uso de alguns conceitos-chave: o ser automediador (ser-por-si-mesmo), e principalmente, a 
alienação (entfremdung), estando ambos interligados.

Naturalmente, a definição de alienação em Marx é, por si só, tema de grandes e complexos estudos, como, por exemplo, o já diversas vezes citado, levado a cabo por István Mészáros (Mészáros, 1981). Seria despropositado seguir agora o desenvolvimento desta grande e detalhada análise em todos os seus passos; ao invés disto, buscarei uma definição resumida da alienação a partir do texto original dos manuscritos, seguindo o raciocínio de Marx. Para tal, podemos sem dúvida partir de uma única frase: "Todas estas conseqüências estão na determinação de que o trabalhador se relaciona com o produto do seu trabalho como //com// um objeto alheio //"fremd"//." (Marx, 1983:150)[9]

Marx localiza a origem de todo o processo de alienação neste único ponto, que é o processo produtivo, muito de acordo com o que viria a elaborar, junto de Engels, poucos anos depois: "A maneira como os indivíduos manifestam sua vida reflete exatamente o que eles são. O que eles são coincide, pois, com sua produção, isto é, tanto com o que eles produzem quanto com a maneira como produzem." (Marx e Engels, 2002:11)

Marx analisa esta alienação, dentro da atividade produtiva, sob sucessivos aspectos. Inicialmente, examina a alienação do produtor com seus produtos. Parte para isto de sua crítica da economia política, e das conclusões da mesma, segundo as quais o trabalhador "é rebaixado à condição de mercadoria e à de mais miserável mercadoria, que a miséria do trabalhador põe-se em relação inversa à potência e à grandeza de sua produção" (Marx, 2004:79).

Assim, o produto de seu trabalho, bem como os meios dele, aparecem como uma força exterior ao trabalhador, e ao final este, ao invés de ser o senhor do objeto, torna-se servo dele - relação precisamente oposta à sugerida por Locke. Isto ocorre porque, como ele, a economia política "dá tudo à propriedade privada e nada ao trabalho", e assim "oculta a alienação na essência do trabalho por não considerar a relação imediata entre o trabalhador (o trabalho) e a produção" (Marx, 1983:152). Precisamente por isto o autor inglês podia considerar como dele a turfa que seu criado cortou (Locke, II. 27): a relação do próprio criado com a turfa lhe era desconhecida, ou por ele deliberadamente ignorada.

Após, passa ao exame da alienação no ato da produção, isto é, a relação do trabalhador não só com o produto de seu trabalho, mas com o próprio trabalho. Este decorre de que o trabalho é externo ao trabalhador, e este não se afirma por aquele, mas pelo contrário, nega-se por ele. Assim sente-se junto a si fora do trabalho, e fora de si quando nele; e sua atividade, aquilo por meio do qual sua vida se manifesta, pertence a outro, é uma perda de tempo - perda de si (Marx, 2004:83). Disto decorre que... 
"[...] o homem (o trabalhador) se sente livremente ativo só ainda em suas funções animais, comer, beber e procriar, no máximo ainda moradia, ornamentos, etc., e em suas funções humanas só //se sente// ainda como animal. O que é animal se torna humano e o que é humano //se torna// animal.

Claro que comer, beber e procriar, etc., também são funções genuinamente humanas. Porém, são animais na abstração que as separa do círculo restante da atividade humana e as faz fins últimos e exclusivos. [...]

[...] a sua vida pessoal - pois o que é vida senão atividade - como uma atividade voltada contra ele mesmo, independente dele, não pertencente a ele. A auto-alienação [Selbstentfremdung], tal como acima a alienação da coisa." (Marx, 1983:154)[10]

Tendo em vista estes dois aspectos da alienação, da coisa e de si mesmo, Marx avalia a seguir o papel da relação do homem com a natureza, a partir da relação do homem consigo mesmo. Como vimos acima, o homem é um "ser genérico"; mais especificamente:

"O homem é um ser genérico //Gattungswesen//, não somente quando prática e teoricamente faz do gênero, tanto do seu próprio quanto do restante das coisas, o seu objeto, mas também - e isto é somente uma outra expressão da mesma coisa - quando se relaciona consigo mesmo como //com// o gênero vivo, presente, quando se relaciona consigo mesmo como //com// um ser universal, //e// por isso livre." (Marx, 2004:83-4)

Não é, portanto, que o homem não seja um animal; ele o é, e como tal deve permanecer com a natureza num "processo contínuo para não morrer". Mas diferencia-se por ser um animal cujo modo de vida - ser genérico - tende a uma universalidade que faça de toda a natureza seu "corpo inorgânico" (Marx, 2004:84): i.e., o castor pode construir, o pássaro pode cantar, o leão pode caçar; mas só o homem pode realizar todas estas coisas. E aqui chegamos ao conceito de "automediação", mencionado acima, que pode expressar bem como, por meio de sua interação com a natureza, o homem faz a si mesmo constantemente, atuando no mundo da liberdade; sem chegar a supor que ele é somente o produto de seus próprios atos, e "não é outra coisa senão aquilo que ele se faz", como disse Sartre (apud. París, 2004:355).

Mas ao estranhar o homem de si e de seus produtos, ou seja, do resultado de sua interação com a natureza e, desta forma, da própria natureza, o processo de alienação 
impede sua atuação como ser universal e, por conseguinte, separa-o de seu ser genérico, aliena-o de sua existência enquanto humano. E por fim, estando alienado de seu gênero, o homem fica também alienado dos demais pertencentes a este, ou seja, o homem torna-se estranho ao próprio homem (Marx, 2004:84-85): a espécie humana inteira aliena-se entre si e se atomiza, tornando-se a raça egoísta e individualista que os pensadores liberais vieram a diagnosticar em seu tempo.

O processo de trabalho moderno aliena, então, o trabalhador: dos objetos de seu trabalho, de si, de seu ser genérico e dos demais homens. Com isso, rebaixa a atividade livre a um meio da existência física, uma mera forma de satisfação das carências (Marx, 1983:158), extinguindo o trabalho - compreendido em sua forma capitalista, como atividade feita em troca de um salário - enquanto pertencente ao mundo da liberdade. Podemos avaliar isto retornando aos três grupos de objetos usados por Mészáros, dos quais o homem pode estar, ou não, livre; e veremos que, sob a influência do processo de alienação, sua independência estará comprometida em todos os três simultaneamente. Ele não está livre da carência natural, pois sua vida inteira é vivida em função desta; não está livre da influência de outros homens, pois depende deles para ter acesso aos mais mínimos requisitos para continuar sua existência, que a eles está sujeita; e por fim não está livre dos entraves ao exercício de seus poderes, pois se encontra alienado de si mesmo. Nas palavras do próprio Marx,

"Um ser se considera primeiramente como independente tão logo se sustente sobre os próprios pés, e só se sustenta primeiramente sobre os próprios pés tão logo deva a sua existência a si mesmo. Um homem que vive dos favores de outro se considera como um ser dependente. Mas eu vivo completamente dos favores de outro quando lhe devo não apenas a manutenção da minha vida, mas quando ele, além disso, ainda criou a minha vida. [...] A criação é, portanto, uma representação ("Vorstellung") muito difícil de ser eliminada da consciência do povo. O ser-por-si-mesmo ("Durchsichselbstsein") [automediador] da natureza e do homem é inconcebível para ele porque contradiz todas as palpabilidades da vida prática." (Marx, 2004:113)

E tudo isto é conseqüência de um único fato: da própria atividade do trabalhador não lhe pertencer, ser propriedade de outro homem. E a propriedade privada é conseqüência, não causa, desta apropriação, que está em sua raiz, bem como, por conseguinte, na raiz do próprio sistema capitalista[11], sendo o divisor de águas para a "decomposição da sociedade nas duas classes dos proprietários e dos trabalhadores sem propriedade" (Marx, 2004:79).

Podemos dizer, então, que o trabalho como atividade livre pertence tanto ao reino da liberdade como ao da necessidade, sendo a forma pela qual o modo de ser humano 
universal manifesta-se sobre a natureza (seu "corpo inorgânico"), mas também a forma pela qual ele realiza suas carências. Isto cobre, porém, apenas uma parcela do caráter do trabalho como necessidade, e precisamente aquela parcela que o homem e o animal têm em comum; cabe agora trabalhar mais cuidadosamente a distinção entre carência e necessidade, o caráter histórico de ambas, e a relação dialética entre os dois mundos dentro do trabalho.

\subsection{Liberdade e Necessidade como Ciclo[12]}

Torna-se agora necessário aprofundar as distinções entre as categorias Bedürfnis e Notwendigkeit (que, conforme já explicado em nota, são vertidas respectivamente para "carência" e "necessidade"), que assumem papéis ligeiramente diferentes na teoria de Marx.

Para tanto, principiemos pelas palavras de Marx e Engels em "A Ideologia Alemã":

“... todos os homens devem ter condição de viver para poder 'fazer história'. Mas, para viver, é preciso antes de tudo beber, comer, morar, vestir-se e algumas outras coisas mais. O primeiro fato histórico é, portanto, a produção dos meios que permitem satisfazer essas necessidades [Bedürfnisse], a produção da própria vida material,[...]

O segundo ponto a examinar é que uma vez satisfeita a primeira necessidade, a ação de satisfazê-la e o instrumento já adquirido com essa satisfação levam a novas necessidades - e essa produção de novas necessidades é o primeiro ato histórico."[13] (Marx e Engels, 2002:21-2)

Isto quer dizer que, se por um lado a História caracteriza-se pela produção de novas carências, as primeiras carências não são historicamente produzidas, o que significa que as carências não são necessariamente históricas (embora tenham, evidentemente, uma existência histórica). No caso das necessidades, não se pode dizer o mesmo:

"Segundo Marx, toda necessidade é uma 'necessidade histórica', ou seja, uma 'necessidade em desaparecimento' ("eine verschwindende Notwendigkeit"). Esse conceito - da 'Grundrisse' - não só torna inteligível as múltiplas transformações e transições dos 
fenômenos sociais em termos de necessidade histórica, como também, ao mesmo tempo, deixa abertas as portas para o desenvolvimento futuro da sociedade humana." (Mészáros, 1981:106)

Para compreender o porquê desta diferença entre uma e outra categoria, vamos recorrer ao raciocínio de Lukács, conforme exposto por Tertulian:

“... a necessidade não deve ser compreendida como um sistema de relação com uma força de coerção trans-histórica determinada. É o que o filósofo chama, com uma expressão parcialmente tomada de empréstimo a Nicolai Hartmann ('a necessidade se-então').[...]

O caráter 'necessário' de um encadeamento de fenômenos está condicionado pela existência de uma premissa determinada: se esta premissa existe, então a instituição da sucessão necessária acontece." (Tertulian, 1996:10)

Diferenças de tradução à parte, embora a análise acima diga respeito muito mais à necessidade do que à carência, ela servirá para expor as bases das distinções entre ambos. Naturalmente, a definição de necessidade como "se-então" encaixa-se claramente na categoria Notwendigkeit, evidenciando sua mencionada oposição à contingência; mas não somente nela: afinal, para viver "é preciso antes de tudo beber, comer, morar, vestir-se e algumas outras coisas mais" - em outras palavras, se quero viver, então devo beber, comer, morar, etc.. Isto é, a carência também segue uma lógica do tipo "se-então", mas seu "se" é sempre um só, o "viver" ou, mais especificamente, viver como ser humano, reproduzir-me como ser humano, sentir-me humano Assim, para tudo aquilo que a vida exige para se manter, reservemos a palavra carência; e chamemos todo o restante de coisas, as quais designamos normalmente "necessidades", como tais: carência, por exemplo, de "comida, diversão e arte", e necessidade de superação da propriedade privada para se atingir o comunismo.

Esta definição mais cuidadosa serve a muitos propósitos, talvez o mais importante deles o de evitar a armadilha comum, que consiste em crer que o homem moderno, tal qual o primitivo, sofreria apenas das mais básicas carências. Nada mais falso: sendo o primeiro ato histórico precisamente a produção da primeira nova carência, a História mesma será também a constante produção de novas carências. Precisamente por isso não só "viver", mas "reproduzir-se como ser humano, sentir-se humano": o significado destas expressões varia com o local e o tempo, e tende a aumentar, particularmente com o advento da modernidade. 
Já as necessidades, por outro lado, por serem históricas, requerem primeiramente a existência do humano, ou seja, a satisfação das carências:

"O homem carente, cheio de preocupações, não tem nenhum sentido para o mais belo espetáculo; o comerciante de minerais vê apenas o valor mercantil, mas não a beleza e a natureza peculiar do mineral; ele não tem sentido mineralógico algum; portanto, a objetivação da essência humana, tanto do ponto de vista teórico quanto prático, é necessária tanto para fazer humanos os sentidos do homem quanto para criar sentido humano correspondente à riqueza inteira do ser humano e natural." (Marx, 2004:110-11)

Portanto, o homem carente não é livre para exercer seus poderes, criar sentido, ou para o que quer que seja, e quanto mais carente ele é, menos livre com relação a mais coisas ele será. Uma perspectiva comum é de que a criação de carências é sinal de aprisionamento, uma determinação; ora, isto só será verdade se as mesmas carências não puderem ser satisfeitas. Do contrário elas colaboram para aumentar e criar sentido(s) humano(s), sua riqueza natural e sua universalidade como ser vivo genérico. De fato, tratar tanto "carência" quanto "necessidade" como determinantes de qualquer coisa já parece, em si, uma presunção arriscada. Tertulian também explicita a postura de Lukács quanto a isto: "Primeiramente, ele se recusa a identificar 'determinação' e 'necessidade'; na esfera das determinações da realidade, suscetíveis de serem valorizadas pelo ato livre, não entra unicamente a necessidade, mas, também a possibilidade e o acaso." (Tertulian, 1996:10)

Aqui a língua presta-se a inúmeras confusões, já que como oposição à contingência (como Notwendigkeit) a palavra "necessidade" assumiria precisamente o sentido de determinação. Isto só pode ser remediado tendo em vista a perspectiva de análise de Lukács, a do "ato livre" como realização da liberdade humana, segundo a qual "determinar" significa fazê-lo com relação à forma de execução deste ato, limitando o ato, e neste sentido devemos concordar com sua análise. P. ex., se dizemos que para se conseguir dinheiro é necessário trabalhar, estamos cometendo uma falácia lógica, já que existem inúmeras outras determinações afora o próprio ato individual "livre"[14] (o que Tertulian chama de "possibilidade" e "acaso") que irão ditar o resultado da ação de trabalhar, além de inúmeras outras formas de se conseguir dinheiro que nada têm a ver com trabalho.

Por outro lado, não identificar em absoluto "necessidade" e "determinação" seria um erro ainda mais grave: o fato de possuir carências e necessidades, a maneira como estas se realizam, e o impacto que exercem na vida são parte essencial do que determina o ser humano, como indivíduo ou coletivamente. E o determinam precisamente como um ser cuja essência é a de um ser livre; de fato, livre também porque determinado. 
Na verdade em Aristóteles já encontraremos os elementos para delinear a maneira pela qual os mundos da necessidade e da liberdade engendram um ao outro. Ele dizia que não podemos deliberar sobre o que é totalmente determinado ou indeterminado - e, conseqüentemente, que o homem que não é determinado não é livre ("Ética a Nicômaco", III, 3, 18-31). Mészáros conduz raciocínio semelhante, mas levando a uma direção própria:

"Mais uma vez, a solução está em afirmar esta limitação como a fonte da liberdade humana. A atividade produtiva, imposta ao homem pela necessidade natural como a condição fundamental da sobrevivência e do desenvolvimento humanos, torna-se assim idêntica à realização humana, isto é, à realização da liberdade humana. A realização, por necessidade lógica, implica limitações, pois só aquilo que é limitado de alguma forma pode ser realizado." (Mészáros, 1981:149-150)

Penso que Mészáros, longe de dizer que determinação e possibilidade, liberdade e necessidade sejam uma só coisa, e que, de forma semelhante ao pensamento liberal, liberdade é a liberdade para suprir suas carências, está apenas afirmando que, na ação produtiva, no trabalho, ambos realizam-se mutuamente, e que há uma relação íntima entre ambos. Tanto que é ele mesmo quem, poucas páginas após, dirá que "as necessidades produzem poderes, tal como os poderes produzem necessidades"[15] (Mészáros, 1981:163), e nada resume melhor esta relação entre os dois mundos. Afinal, a liberdade liga-se a um poder correlato - ela nada é sem a possibilidade, e esta última por sua vez está intimamente ligada ao poder, a um ponto em que por vezes as formas diversas das palavras ("posso", "possível") chegam a confundir-se. E um ser humano é livre para pensar e agir apenas quando pode, efetivamente, fazê-lo - simplesmente outorgar-lhe esta capacidade em palavras sem que ele possua, de fato, o poder para tanto, constituirá apenas especulação, o que Zygmunt Baumann designa como o enorme abismo entre o indivíduo de jure e o indivíduo de facto (Baumann, 2001:48)[16].

Isto vale em inúmeros sentidos, começando pelo da carência: como vimos acima, onde o homem é carente, nada pode; ele é escravo de suas carências, que onde existem o determinam. Por outro lado, o poder para satisfazê-las, quando existente, se transformado no de criar novas carências e necessidades, passa a ser também manifestação da liberdade. Já a necessidade lógica nasce, por sua vez, das relações entre querer e poder: o primeiro impõe condições, um "se" para cada "então", cuja realização é necessária para que o segundo alcance efetividade. Mas é notável que, no que concerne às necessidades do homem, ele mesmo tem papel fundamental na determinação destas condições, pois o resultado das escolhas de hoje determinarão em parte tanto o querer quanto o poder de amanhã. 
Esta breve incursão pela teoria marxista nos permite vislumbrar, então, que necessidade e liberdade estão num processo de geração mútua; que o mundo do trabalho é expressão da necessidade, mas pode ser expressão da liberdade quando exercido de maneira não-alienada; e que a liberdade só existe de forma efetiva se puder tornar-se um poder, e não apenas um teórico abrir de grilhões: quer da carência natural, quer dos demais homens, o ser humano não é livre porque deixado a sós consigo mesmo, mas só o é se pode efetivamente exercer seus próprios poderes.

O Direito moderno tem sido unânime em afirmar, como vimos anteriormente, bem ao gosto de John Locke, a igualdade entre os indivíduos "por natureza", e a liberdade de cada um deles, bem como seu direito ao trabalho. Qual direito, qual igualdade, e até que ponto ambos são de fato protegidos pelo atual sistema é o que buscaremos avaliar a seguir.

\section{TRABALHO: DIREITO E DEVER?}

Fica claro já em seu título que este artigo lida principalmente com duas problemáticas centrais, sendo uma a dos direitos e deveres, e outra, de escopo muito maior, a da liberdade e da necessidade. Estes dois mundos convivem com uma ligação visível, porém pouco clara, entre si, dentro do mundo do trabalho; e são, à primeira vista, manifestações um do outro em planos diferentes da atuação humana: liberdade e necessidade no plano "natural", direito e dever, no "social".[17] Este artigo seguirá, então, para agora tentar traçar esta ligação e, a partir disto, obter uma definição dos direitos e deveres que possa servir de ferramenta adequada à investigação deste caráter particular do trabalho.

\subsection{Direitos e Deveres como Ações e Abstenções}

Após analisar brevemente o caráter de geração mútua da relação da liberdade com a necessidade, passemos aos direitos e deveres. Sobre esta segunda problemática de conceitos complementares, ficou notado anteriormente que o mesmo pertencia à parte específica da natureza, isto é, à sociedade humana, e de fato pertence; mas também é parte ainda mais específica, dizendo respeito ao Direito. Este, no entendimento de Miguel Reale,... 
"[...] corresponde à exigência essencial e indeclinável de uma convivência ordenada, pois nenhuma sociedade poderia subsistir sem um mínimo de ordem, de direção e solidariedade. É a razão pela qual um grande jurista contemporâneo, Santi Romano, [...] concebeu-o antes como 'realização de convivência ordenada'."[18] (Reale, 1998:2)

Aproveito esta definição para repassar duas distinções fundamentais da Teoria do Direito. Primeiro, a evidente distinção entre o Direito e os direitos, em que o primeiro é precisamente a "realização da convivência ordenada" a que se refere Santi Romano, sendo os direitos muitos, tanto no sentido de serem muitos seus ramos e divisões (direitos constitucional, civil, administrativo, etc.; direitos público e privado; direitos objetivo e subjetivo...), quanto no de direitos subjetivos, possuídos por sujeitos de direito assim como os muitos deveres. Razão mesma pela qual, a seguir, é importante distinguir direito subjetivo de direito objetivo. Maria Helena Diniz nos diz que...

"O direito objetivo é o complexo de normas jurídicas que regem o comportamento humano, de modo obrigatório, prescrevendo uma sanção no caso de sua violação (jus est norma agendi).

O direito subjetivo, para Godofredo Telles Jr., é a permissão dada por meio de norma jurídica, para fazer ou não fazer alguma coisa, para ter ou não ter algo, ou, ainda, a autorização para exigir, por meio dos órgãos competentes do poder público ou por meio de processos legais, em caso de prejuízo causado por violação de norma, o cumprimento da norma infringida ou a reparação do mal sofrido.[...]

O direito subjetivo é subjetivo porque as permissões, com base na norma jurídica e em face dos demais membros da sociedade, são próprias das pessoas que as possuem, podendo ser ou não usadas por elas." (Diniz, 2002:10-1)

Cabendo notar que esta divisão é mera convenção, não podendo o direito subjetivo ser concebido sem correspondência com o direito objetivo (Reale, 1998:260), já fica evidente que nossa análise irá ocupar-se muito mais do primeiro, uma vez que o direito ao trabalho é claramente um direito subjetivo (assim como o dever), e este deve dizer respeito ao direito de fazer algo. De fato, se há uma crítica a ser feita à definição de Telles, oferecida por Diniz, é que os direitos de ter ou não ter, bem como a autorização para exigir a realização destes direitos, não passam de uma modalidade específica dos de fazer ou 
não fazer (no caso, fazer ou não fazer algo com a propriedade). Ao fim e ao cabo, são todos direitos de fazer ou não fazer, simplesmente, e demais classificações não passam de especificações convenientes[19].

Quanto aos direitos terem por requisito sua própria efetividade, cabe acrescentar que isto vale não só para eles, mas também para o próprio Direito como um todo:

"Direito, não destinado a converter-se em momento de vida, é mera aparência de Direito. Norma de direito que enuncia uma possibilidade de fazer ou de pretender algo, sem que jamais surja o momento de sua concretização na vida dos indivíduos e dos grupos como ação ou pretensão concretas, é uma contradição em termos." (Reale, 1998:260)

Por isso, como diz Bobbio,

“... assim como não existe pai sem filho e vice-versa, também não existe direito sem obrigação e vice-versa. [...] Pode-se falar de direitos morais só no âmbito de um sistema normativo moral, onde haja obrigações cuja fonte não é a autoridade munida de força coativa, mas Deus, a própria consciência, a pressão social, a depender das várias teorias da moral." (Bobbio, 2004:94)

Assim, em última instância, o elemento caracterizador da existência da ordem jurídica é precisamente aquele que garante sua efetividade, isto é, a coação, visto a obrigação só poder ser entendida como tal enquanto o sujeito dela for, de fato, obrigado a tanto. E é característico dos sistemas jurídicos, ao contrário dos éticos, morais, religiosos e demais sistemas sociais, predeterminar e organizar suas sanções de forma a garantir sua efetividade (Reale, 1998:74). C Claro, como a convivência ordenada geralmente se dá por meio da adoção de regras, majoritariamente restritivas, e estas são caracterizadas justamente por essa forma de sanção, por muitas vezes o Direito parece confundir-se com a lei, o que é falso. Reale nos lembra, aplicando a consagrada lição de que ubi societas, ibi ius, que mesmo as formas mais rudimentares de vida social já implicam um esboço de ordem jurídica (Reale, 1998:2). Por isto faz parte do Direito todo tipo de norma que efetivamente gere condutas que permitam a convivência, podendo ser uma conduta por ação ou por abstenção de agir, não ficando os direitos ou os deveres restritos ao âmbito da lei.

Assim, quando uma conduta, quer seja da parte de um indivíduo ou de um grupo, é normativamente aceita (permitida), podemos dizer que isto constitui um direito subjetivo, 
porque já aplicado ao sujeito; e, quando exigida, um dever igualmente subjetivo (obrigação), contanto que as respectivas sanções sejam previstas e organizadas antecipadamente; caso contrário não há norma e, sem esta, não há sentido em se falar em Direito[20].

\subsection{Liberdade e Necessidade, Direitos e Deveres}

Aproxima-se o ponto onde poderemos verificar se a correspondência direitoliberdade e dever-necessidade é, de fato, pertinente.

Afinal, qualquer imperativo (dever) advindo do convívio social, seja ele jurídico ou não, parte do princípio de que o sujeito optou por sua inserção naquele grupo, das formas de construção do poder que ele assume ou, ao menos, que ele voluntariamente submeteuse ao mesmo - seguindo a visão de Locke e de muitos outros, assume um poder político e, conseqüentemente, jurídico, construído a partir do consenso e da voluntária submissão à autoridade (II, 87 e ss.). Estaria, portanto, por meio desta submissão, a exercer sua liberdade, e caso julgasse não valer à pena submeter-se a determinado sistema poderia muito bem simplesmente não fazê-lo, mantendo-se no "estado de natureza" ou mesmo escolhendo filiar-se a outro governo.[21]

Sob esta ótica, o exercício do dever torna-se, pelo contrário, uma manifestação maior da liberdade - mas tal ótica é enganosa. Ela assume um homem não-histórico e o pressupõe sempre amplamente capaz de exercer e fazer valer sua liberdade, o que vimos estar longe da realidade para todos aqueles que devem não apenas a manutenção de suas vidas, mas a própria criação de suas vidas a outros (v. Marx, 2004:113, e acima). Por outro lado, como já vimos, a criação de carências é o primeiro ato histórico, sendo também uma expressão da ligação entre os dois mundos, e a escolha gera sempre necessidades. Neste sentido, pode haver liberdade simultânea ao dever, mas não no dever. Retornaremos a isto em breve.

Torna-se importante, antes, explicitar a posição dos deveres no mundo da necessidade. Deveres não são carências: não são imposições essenciais à reprodução do ser humano enquanto tal. Mas mais que isto, não estamos tratando aqui do trabalho como dever moral ou ético (embora esta seja uma ótica perfeitamente válida), e sim do dever jurídico, isto é, a obrigação que é o contraponto de um direito, garantida por uma sanção prevista em norma. Como tal ele é um determinante do indivíduo - embora não possa nunca determiná-lo totalmente, ele reduz drasticamente suas opções, coagindo-o a um determinado curso de ação. 
Sob esse critério, podemos ver como o trabalho, apesar de fazer parte do mundo da necessidade, freqüentemente não é considerado como dever jurídico pelo simples fato de que nenhuma norma obrigaria sua realização - o que não é verdade. $E$, de fato, muitos tomam o trabalho somente como direito, mesmo residindo no Brasil, esquecendo-se de "uma norma legal draconiana, injusta e parcial", nas palavras do juiz criminal Moacir Danilo Rodrigues (apud Jorge, 2007) como a arcaica lei da vadiagem, e sua lei-irmã, a da mendicância, dispositivos legais que remetem aos tempos de John Locke:

"Art. 59 - Entregar-se alguém habitualmente à ociosidade, sendo válido para o trabalho, sem ter renda que the assegure meios bastantes de subsistência, ou prover a própria subsistência mediante ocupação ilícita:

Pena - prisão simples, de 15 (quinze) dias a 3 (três) meses.

Parágrafo único - A aquisição superveniente de renda, que assegure ao condenado meios bastantes de subsistência, extingue a pena.

Art. 60. Mendigar, por ociosidade ou cupidez:

Pena - prisão simples, de quinze dias a três meses.

Parágrafo único. Aumenta-se a pena de um sexto a um terço, se a contravenção é praticada:

a) de modo vexatório, ameaçador ou fraudulento.

b) mediante simulação de moléstia ou deformidade;

c) em companhia de alienado ou de menor de dezoito anos." (Brasil, 2007)

Isto é, não possuir um trabalho assalariado ou qualquer outra fonte de renda, sendo capaz para tanto (o que quer que isto queira dizer) é, em nosso país, proibido, estando o cidadão obrigado por lei a ganhar dinheiro, no caso de não ter riqueza própria; e mesmo que não possa fazê-lo, também não terá nem ao menos a chance de pedir por ele 
em público, o que é, igualmente, proibido.

Muito embora pareça "evidente que a simples pretensão de punir aqueles que a sociedade já condenou à exclusão social, à fome e ao desespero revela uma crueldade talvez insuperável em nosso ordenamento jurídico" (Rolim apud. Jorge, 2007), tal lei permanece em vigor no país e, apesar dos esforços de alguns intérpretes da lei, capazes de enxergar seu absurdo, continua muitas vezes a ser aplicada, tornando também contraventores os desempregados, pedintes e miseráveis. Embora as razões para esta crueldade possam ser diretamente traçadas a partir da ética pela qual o trabalho dignifica o homem, tão cara a Weber pelo papel que teve para o progresso do sistema capitalista[22], tal análise oferece uma perspectiva do trabalho como dever moral, pouco dizendo do caminho que o levou de mero preceito ético-religioso a uma norma de direito acompanhada de sanção.

Por que, afinal, a sociedade atual teria interesse em reprovar um cidadão simplesmente por sua ociosidade ou atividade mendicante, quando no passado estes últimos foram sempre aceitos[23] e os primeiros até admirados? Mais especificamente, por que fazê-lo desta forma? Dizer que o trabalho é um dever moral não é explicação o suficiente para a punição de um homem "não-trabalhador", em primeiro lugar porque ele é considerado como tal apenas por não possuir um trabalho assalariado, ou seja, na forma alienada; e segundo porque, se ele possui mesmo o direito ao trabalho, então tal direito devia ser assegurado a ele por outros, e não cobrado como se dever fosse. Ainda assim, às massas de desempregados é dito que seu desemprego é precisamente culpa sua e de mais ninguém: "ser um indivíduo de jure significa não ter ninguém a quem culpar pela própria miséria, significa não procurar as causas das próprias derrotas senão na própria indolência e preguiça, e não procurar outro remédio senão tentar com mais e mais determinação." (Baumann, 2001:48)

Assim é que não só eles, mas o próprio senso comum vem a julgar como imoral e passível de punição o "ócio", a "vadiagem" e a mendicância, que acabam tendo de conviver não só com a própria pobreza, mas com o desprezo e até o ódio de seus semelhantes[24].

Mas é possível que seja mesmo ao trabalho que esta lei obrigue? Ou ainda, é possível que algo seja, juridicamente falando, direito e dever ao mesmo tempo? E se não for, ao que, então, nossa jurisdição obriga?

\subsection{Da Possibilidade de Coexistência Simultânea de Direitos e Deveres}


Dizer que o trabalho é um dever pode mesmo parecer neste momento a enunciação do óbvio. Nossa única evidência em contrário é a conclusão, também derivada da análise anterior, de que, estando os direitos no mundo da liberdade, e os deveres, no da necessidade, e sendo um o complemento do outro, não podem confundir-se - embora no senso comum, e mesmo em boa parte do pensamento filosófico e, especificamente, jurídico, freqüentemente o façam. Vide a concepção comumente aceita de que, segundo o art. 14 de nossa Constituição Federal (Brasil, 1988), o voto seria, ao mesmo tempo, tanto um direito quanto um dever.

Neste ponto é preciso retomar um ponto que foi propositadamente deixado de lado até aqui, que é a relação entre a fruição e a liberdade (e, conseqüentemente, os direitos). Creio que uma frase comumente repetida pode evidenciar o que me leva a isto: "tempo livre é tempo de fruição". Aqui vemos uma ligação da idéia de liberdade, não tanto com a capacidade de optar, autodeterminar-se, mas com a de fruir de maneira mais ampla; não que uma exclua a outra, ou ainda que o ato de optar não seja, em si, uma fruição justamente, é fruir das próprias faculdades deliberativas - mas sim que é preciso compreender que, justamente por estar o mundo da liberdade no limiar entre a determinação e a indeterminação absolutas, ele deve ligar-se à fruição. Não é de se admirar, portanto, que a confirmação de nossa distinção entre direito e dever, visto a relação de ambos com a fruição, o desejo, o gozo, etc., possa vir de um psicanalista:

"Esclarecerei com uma palavra a relação do direito com o gozo. O usufruto - é uma noção de direito, não é? - reúne numa palavra o que já evoquei em meu seminário sobre a ética, isto é, a diferença que há entre o útil e o gozo. [...] O usufruto quer dizer que podemos gozar de nossos meios, mas que não devemos enxovalhá-lhos. [...] É nisso mesmo que está a essência do direito - repartir, distribuir, retribuir, o que diz respeito ao gozo.

O que é o gozo? Aqui ele se reduz a ser apenas uma instância negativa. O gozo é aquilo que não serve para nada.

Aí eu aponto a reserva que implica o campo do direito-ao-gozo. O direito não é o dever. Nada força ninguém a gozar, senão o superego.(...)" (Lacan, 1985:11)

Sem deixar de notar que Lacan fala aqui do gozo absoluto (assunto no qual não cabe em absoluto aprofundarmo-nos), e que nenhuma das categorias aqui utilizadas (especialmente as diversas formas de fruição) é, como este, apenas uma instância negativa, veremos que a despeito disto suas afirmações clarificam o alcance do dever, 
jurídico ou não. A liberdade e a necessidade também são distintos e, no entanto, convivem no trabalho. Isto se dá não só pela natureza ampla e dialética de ambos, que coexistem em quase todos os aspectos da vida humana, mas também porque o próprio trabalho, aliás todo ato humano, não pode ser visto como unitário e indivisível. Assim podemos também concluir sem medo que aqueles que dizem ser o voto simultaneamente direito $\mathrm{e}$ dever ou confundem-se, ou em verdade querem dizer ser parte do ato de votar uma coisa, e parte, outra.

Fica claro que direitos e deveres têm objetos distintos, sendo que o gozo, e até certo ponto muitas das formas de fruição, porém, não podem nunca ser objeto de um dever[25]; e pode-se obrigar alguém a qualquer coisa, mas não a gostar - pode-se convencê-lo, seduzi-lo, etc., mas não forçá-lo. É assim que mesmo nos deveres pode subsistir o mundo da liberdade; o fazer ou não-fazer do dever, porém, é objeto distinto, por exemplo, do gozo que pode haver neles. E mesmo que haja fruição de qualquer forma no trabalho, seja por meio do que Lukács chamou "externação" (Tertulian, 1996:12), pelo sentimento de integração social ou o que quer que seja, esta fruição, aos olhos do Direito, não se confunde com o ato de trabalhar. E havendo obrigação ao ato de trabalhar, basta isto para configurá-lo como dever e não direito.

Vemos que a contradição aparente do trabalho como liberdade e necessidade já mostrou ser apenas aparente. Já a do trabalho como direito-dever - esta sim é ainda contraditória, e a parte crucial da pseudoconcreticidade que, desde a introdução, temos buscado destrinchar, para poder dizer, afinal, o que é o trabalho: direito ou dever? Ou, em sendo ambos, qual parte é cada um?

\section{4 - Invalidação da Idéia de Trabalho como Dever sob as Relações Capitalistas de Produção}

É em Marx, novamente, que daremos outro grande passo neste sentido, por meio de sua "Crítica da Filosofia do Direito de Hegel", quando da análise do parágrafo 261 dos "Princípios da Filosofia do Direito" deste último:

"O parágrafo precedente nos ensina que a liberdade concreta consiste na identidade (normativa, dúplice //sein sollende, zwieschlächtige//) do sistema de interesses particulares (da família e da sociedade civil) com o sistema do interesse geral (do Estado).[...] 
Hegel estabelece, aqui, uma antinomia sem solução. De um lado, necessidade externa; de outro, fim imanente. A unidade do fim último geral do Estado e dos interesses particulares dos indivíduos deve consistir em que seus deveres para com o Estado e seus direitos em relação a ele sejam idênticos.[...]

O que serve de mediação para a relação entre o Estado, a família e a sociedade civil são as 'circunstâncias, o arbítrio e a escolha própria da determinação'. A razão do Estado nada tem a ver, portanto, com a divisão da matéria do Estado em família e sociedade civil. $O$ Estado provém delas de um modo inconsciente e arbitrário. Família e sociedade civil aparecem como o escuro fundo natural donde se acende a luz do Estado." (Marx, 2005:278-9)

Ora, como acabamos de ver, direitos e deveres não podem conviver simultaneamente num único objeto; da mesma forma, a unidade do fim último do Estado com os interesses particulares não pode existir integralmente: é uma relação dialética em que haverá momentos de correspondência e divergência. Quando tal correspondência ocorre (ou parece ocorrer) na totalidade, ela significa apenas que uma das partes impôs-se sobre a outra - e que o fim do Estado suplantou os interesses particulares, ou o contrário. [26] Fazer crer que este par possa como que se unir num matrimônio transcendental não é nada além de mascarar estes processos sob um véu mágico, que simultaneamente desfaz as cadeias de causalidade históricas e confere falsa autonomia ao que deveria ser 0 Estado. O raciocínio não precisa restringir-se a esta aplicação, e sofismas semelhantes podem ser usados para propósitos igualmente similares.

Façamos novo détour: para melhor compreender o dever ao trabalho, compreendamos o direito ao trabalho. Não faz sentido a esta altura iniciar uma investigação da Consolidação das Leis Trabalhistas. Embora seja em seus artigos que encontremos as normas que diretamente garantem os direitos dos trabalhadores, sabemos que elas só valem enquanto garantidoras dos princípios expostos pelas leis hierarquicamente superiores - justamente com as quais iniciamos nossa indagação. Retornemos a elas, a começar pelo art. $5^{\circ}$ de nossa Constituição.

"Art. $5^{\circ}$ Todos são iguais perante a lei, sem distinção de qualquer natureza, garantindo-se aos brasileiros e aos estrangeiros residentes no País a inviolabilidade do direito à vida, à liberdade, à igualdade, à segurança e à propriedade, nos termos seguintes:

$[\ldots]$

XIII - é livre o exercício de qualquer trabalho, ofício ou profissão, atendidas as qualificações profissionais que a lei estabelecer." (Brasil, 2005) 
Já muito foi dito das numerosas garantias que este artigo teoricamente proporciona, e da incapacidade de torná-las efetivas. Mas o que nos interessa aqui é a ligação entre estes direitos, enunciados no caput e chamados, com razão, "fundamentais", e o mundo da liberdade, já que todos os direitos restantes do artigo, incluído aí o direito ao trabalho, são subsidiários destes - isto é, somente as formas pelas quais os direitos do caput, à vida, à liberdade, à igualdade, à segurança e à propriedade, realizam-se. O direito ao trabalho não é, portanto, fim em si mesmo; o que nos permite ver que sua posição no mundo da liberdade, pela Constituição, será a de procurar garantir que carências sejam adequadamente supridas, abrindo espaço para o desenvolvimento livre dos indivíduos. Nada mais adequado do que o uso que faço da palavra "carências", visto que os direitos fundamentais são precisamente aqueles tidos como absolutamente necessários à reprodução do homem enquanto homem.

A "Declaração Universal dos Direitos do Homem" não só segue no mesmo sentido, como nos dá pista do que significa suprir carências se prestarmos a devida atenção ao trecho: "Quem trabalha tem direito a uma remuneração eqüitativa e satisfatória, que lhe permita e à sua família uma existência conforme com a dignidade humana, e completada, se possível, por todos os outros meios de proteção social." (ONU, 2006)

"O conceito de direito ao trabalho (remunerado) surge no campo político no mesmo momento em que Estados Unidos e França, as primeiras democracias modernas, faziam do direito de propriedade a pedra angular de sua constituição. Os dois direitos eram face e contraface do processo de afirmação do capitalismo emergente, que privatizou os instrumentos de trabalho e separou os trabalhadores dos meios de produção.[...]

[...] já os contemporâneos dos primórdios do capitalismo - e, sobretudo, da democracia moderna - tiveram a clara percepção de que, na ausência de mecanismos para assegurar alguma forma de renda aos não-proprietários, havia uma contradição evidente entre direito de cidadania na democracia representativa e direito à propriedade privada dos meios de produção." (Assis, 2002:27)

Como podemos ver, dentro do capitalismo, sem renda o ser humano não só tem que enfrentar todas as carências naturais, como também perde o acesso à cidadania não só à propriedade, à igualdade e à liberdade, mas também à segurança e até à vida. Pois no sistema capitalista o que permite a satisfação das carências, a reprodução do homem enquanto homem, e a única coisa que o permite, é a remuneração - o dinheiro. 
"O homem se torna cada vez mais pobre enquanto homem, carece cada vez mais de dinheiro para se apoderar do ser hostil, e o poder de seu dinheiro cai precisamente na relação inversa da massa de produção, ou seja, cresce sua penúria //Bedürftigkeit// à medida que aumenta o poder do dinheiro. - A carência de dinheiro é, por isso, a verdadeira carência produzida pela economia nacional [política] e a única carência que ela produz." (Marx, 2004:139)

Não é que todas as carências diversas tenham desaparecido, e sim que o dinheiro é o poder de realizar todas, poder que deriva de sua permutabilidade universal, cuja base é justamente a transformação de todas as relações do homem, com a natureza, com os outros e consigo mesmo, em relações de propriedade.

"A secularização do conceito religioso de alienação realizou-se nas afirmações concretas relacionadas com a 'vendabilidade'. [...] Até mesmo a doutrina da 'queda do homem' teve de ser questionada - como foi por Lutero, por exemplo - em nome da 'liberdade' do homem. Essa defesa da 'liberdade', porém, revelou-se na realidade nada mais do que a glorificação religiosa do princípio secular da 'vendabilidade universal'." (Mészáros, 1981:34-5)

Voltemos então ao direito ao trabalho: o que exatamente ele busca garantir? Não é uma relação criadora do homem com a natureza, não é uma atividade gratificante (fruição), não é a "externação" de Lukács: é a renda. Por isso ele é uma garantia ao trabalho remunerado - de fato, é muito fácil a qualquer um conseguir trabalho não-remunerado, e para isso nenhuma norma é necessária.

E o dever? Uma análise mais aguda da lei da vadiagem nos mostrará que ela em verdade não versa, em absoluto, sobre um dever ao trabalho; não há obrigação de trabalhar. Ou melhor, só o há para aqueles que não possuem renda que lhes assegure meios para a subsistência. Não há dever ao trabalho, há somente o dever à renda, ao lucro. E é aqui que os direitos e deveres se confundem, pois parece haver tanto o direito quanto o dever a eles - e de fato parece tanto dos interesses particulares quanto do Estado que todos possuam renda. Mas nós mesmos já vimos que Marx derruba essa idéia [27], e que a geração de lucro, assim como a permutabilidade universal, pouco interessam ao trabalhador destituído de meios de produção, e na economia capitalista sua miséria "põe-se em relação inversa à potência e à grandeza de sua produção".

É que em realidade o direito dos trabalhadores, bem como seu interesse, aliás 
como também o dos proprietários, não é o dinheiro em si, e sim o que ele pode proporcionar. A diferença crucial entre as duas classes, porém, é que para a primeira a permutabilidade universal, a alienação, o modo de produção capitalista, enfim, a propriedade privada, é uma imensa desvantagem. Sob sua égide, o trabalhador torna-se...

"tanto mais pobre quanto mais riqueza produz, quanto mais a sua produção aumenta em riqueza e extensão. [...] Com a valorização do mundo das coisas //Sachenwelt// aumenta em proporção direta a desvalorização do mundo dos homens //Menschwelt//.[...]

Segundo este duplo sentido, o trabalhador se torna, portanto, um servo do seu objeto." (Marx, 2004a:81)

Em outras palavras, a coincidência de interesses das classes não existe, nem tampouco a dos interesses individuais com o fim do Estado. Pelo contrário, este impõe a existência da propriedade privada como fim em si mesmo, servindo, portanto ao interesse particular de uma classe em detrimento da outra. Fazer crer que os interesses das classes e do Estado são os mesmos, fazer do trabalho tanto direito quanto dever jurídico, é conferir falsa autonomia não só ao próprio Estado, mas à instituição que ele declaradamente busca proteger - a propriedade privada[28]. E como já vimos, esta última não é fundamento do trabalho alienado, mas conseqüência do mesmo (Marx, 2004:87). Assim, a autonomia de uma é autonomia de outro; o dever para com a propriedade privada torna-se, para uns, fruição da mesma, para outros, o dever ao trabalho alienado.

Chegamos, afinal, a uma conclusão: no atual ordenamento, há um direito teoricamente garantido (mas não efetivamente assegurado) ao trabalho remunerado, como meio de garantir a reprodução da classe não-proprietária; e um dever de possuir renda para o sustento próprio. Mas não há nenhum dever ao trabalho: nenhuma lei ou norma o obriga - basta ter renda.

\subsection{Trabalho e Dinheiro}

Até aqui limitamo-nos a analisar a existência do trabalho como dever apenas do ponto de vista do direito positivo, terminando por negá-la em absoluto. A lei é, porém, apenas uma das fontes de Direito, ao lado dos princípios, da moral, dos costumes e da 
jurisprudência, e nossa investigação não deve deter-se nela. Por outro lado, em parte, ao longo de nosso détour já demos conta de algumas destas outras fontes.

Ora, analisar o artigo $5^{\circ}$ da Constituição significou precisamente analisar os princípios que regem o sistema normativo no que tange aos direitos fundamentais, por ele elencados; e entre estes está o direito à propriedade, sendo o direito ao trabalho, como já vimos, apenas um substituto a ele, quando muito um meio para realizá-lo. E embora em seu artigo $1^{\circ}$, inciso IV, ela alegue como fundamento os valores sociais do trabalho, bem como, mais adiante (art. $5^{\circ}, \mathrm{XXIII}$ ), a função social da propriedade, princípios que são reforçados diversas vezes ao longo do corpo da Carta Magna, nem uma coisa nem outra desfazem totalmente a prevalência da propriedade privada e, portanto, do trabalho alienado. Na prática, o que mais freqüentemente se vê como conseqüência disto é justamente a medida tanto do valor do trabalho quanto da função social da propriedade pelo lucro que geram.

Estes princípios não fazem mais que seguir a direção da moral e dos costumes: neles também o dever ao trabalho confunde-se com o dever para com a propriedade privada. Embora se reprove aquele que não se esforça para conseguir um trabalho assalariado, e até mesmo aquele que se esforça sem sucesso, reprova-se muito mais quem, sem sustento próprio, ainda assim recusa-se a aceitar a jaula do trabalho alienado, dê-se essa recusa como for - na melhor das hipóteses, portadores da alcunha de "irresponsáveis", "ingênuos" ou "idealistas; na pior, vistos como vagabundos imprestáveis que não só não merecem a segurança do estatuto jurídico, como são seus inimigos declarados e devem ser tratados como tal[29].

Como bem observa o juiz Rodrigues:

"[...] na escala de valores utilizada para valorar as pessoas, quem toma um trago de cana, num bolicho da Volunta, às 22 horas e não tem documento, nem um cartão de crédito, é vadio. Quem se encharca de uísque escocês numa boate da Zona Sul e ao sair, na madrugada, dirige (?) um belo carro, com a carteira recheada de "cheques especiais", é um burguês. Este, se é pego ao cometer uma infração de trânsito, constatada a embriaguez, paga a fiança e se livra solto. Aquele, se não tem emprego é preso por vadiagem. Não tem fiança (e mesmo que houvesse, não teria dinheiro para pagá-la) e fica preso." (apud. Jorge, 2007)

Mais do que uma observação pontual sobre o absurdo da contravenção da vadiagem, a sentença de Rodrigues é uma percepção geral do tratamento distinto que não apenas a justiça, mas a sociedade como um todo, dá aos indivíduos, de acordo com sua 
situação como proprietário ou sem propriedade - situação imediatamente evidenciada pelo dinheiro.

"O dinheiro, na medida em que possui o atributo de tudo comprar, na medida em que possui o atributo de se apropriar de todos os objetos, é, portanto, o objeto enquanto possessão eminente. A universalidade de seu atributo é a onipotência de seu ser; ele vale, por isso, como ser onipotente.[...]

O que é para mim pelo dinheiro, o que eu posso pagar, isto é, o que o dinheiro pode comprar, isso sou eu, o possuidor do próprio dinheiro. Tão grande quanto a força do dinheiro é a minha força." (Marx, 2004a:157-9)

Tal tratamento diferenciado não é, pois, mais que reflexo da realidade efetiva, na qual o dinheiro torna-se um poder de fato por meio da permutabilidade universal. $\mathrm{E} o$ dinheiro, o capital, por sua vez não é nada mais que "uma certa quantidade de trabalho armazenado e posto de reserva”. (Adam Smith, apud. Marx, 2004:40) É a alienação, o estranhamento do trabalho (Entfremdung) que gera a propriedade privada e dá poder ao dinheiro.

Não por acaso Marx diz que este último tem o poder de "obrigar os contraditórios a se beijarem" (Marx, 2004:161). Ele torna o vadio e rico um modelo de trabalhador a ser invejado e seguido, e o trabalhador, vadio; faz da defesa dos direitos humanos a defesa do mundo das coisas; transforma o dever ao trabalho no dever para com o capital - para com ele mesmo, dinheiro.

Nada disso quer dizer, porém, que não haja nenhum dever ao trabalho. Pelo contrário, é mesmo sua existência como dever ético e moral que sustenta a ilusão do dever jurídico para com o dinheiro; mas enquanto este último pode ser negado, a primeira deve ser não só afirmada, mas posta em evidência: sem trabalho como mediação, não só todo o sistema capitalista, como a própria reprodução do ser humano é impossível. Quem não se socializa para este dever, como sinaliza Gramsci, passa a se considerar como "mamífero de luxo" - mas não um dever ao trabalho em sua versão alienada, e sim como tomada de ação no sentido da manutenção e melhora da vida comum, partindo de cada um de acordo com suas possibilidades, e a cada um de acordo com suas necessidades. $O$ próprio conceito de capital, conforme enunciado pelo próprio pai da economia política, faz de qualquer idéia da superação da centralidade do trabalho dentro do sistema capitalista nada mais que uma piada insossa; e a própria inserção do trabalho no mundo da liberdade e da necessidade, conforme vista ao longo deste artigo, não deixa dúvidas de que ele é 
essencial ao homem e à sociedade, sendo assim interesse e obrigação de todos. É sua forma alienada que permite a desigual atribuição deste dever, bem como a justificativa moral para a exclusão e marginalização daqueles que o próprio sistema não pode absorver.

Ora, a característica marcante do dever, como evidenciado em nossa pequena exposição, é tratar-se de um imperativo social. O dever ético e moral ao trabalho é a priorização do atendimento às necessidades socialmente geradas em lugar das pessoais (preferivelmente por meio da construção de uma sociedade capaz de refletir uma coisa na outra). Diz-se geradas porque a sociedade, como um todo, não tem a capacidade de escolher, ao menos não à maneira do indivíduo. Os deveres impõem, portanto, por seu caráter imperativo, a resolução de necessidades que não podem ser individualmente escolhidas ou contestadas, surgindo, numa sociedade marcada pela cisão de classes e pela alienação, como causais.[30]

Aquele que alega que a posse do dinheiro e o pagamento dos impostos encerram seus deveres para com a sociedade enxerga apenas seu dever para com a propriedade, e não é menos servo dela que o trabalhador alienado: "Observe-se inicialmente que tudo o que aparece no trabalhador como atividade da exteriorização, da alienação, aparece no não-trabalhador como estado de exteriorização, de alienação." (Marx, 1983:163)

Afirmar, então, a existência do trabalho em seu valor como dever ético e moral, negando-o em sua forma alienada, é um passo necessário tanto na afirmação dos valores humanos, como na formação de cidadãos verdadeiramente livres - pois o homem alienado é um homem desumanizado, e, novamente nas palavras de Marx:

"Pressupondo o homem enquanto homem e seu comportamento com o mundo enquanto um //comportamento// humano, tu só podes trocar amor por amor, confiança por confiança, etc. Se tu quiseres fruir da arte, tens de ser uma pessoa artisticamente cultivada; se queres exercer influência sobre outros seres humanos, tu tens de ser um ser humano que atue efetivamente sobre os outros de modo estimulante e encorajador. Cada uma das tuas relações com o homem e com a natureza - tem de ser uma externação //Äusserung// determinada de tua vida individual efetiva correspondente ao objeto da tua vontade." (Marx, 2004a:161)

\section{CONSIDERAÇÕES FINAIS}

O tema abordado, bem como as conclusões até aqui alcançadas, têm especial 
importância, mormente nesta fase caracterizada por vários autores como de mundialização do capital. Por esta razão buscarei nestas considerações finais relacionar a análise aqui empreendida a alguns aspectos que julgo importantes como desafios a enfrentar.

Com efeito, embora a conclusão do capítulo anterior tenha atingido o objetivo pretendido, definindo o direito ao trabalho e negando sua existência como dever do ponto de vista normativo sob as relações sociais capitalistas, seu desenvolvimento tocou ainda mais problemas não resolvidos, que se somam às questões enunciadas na introdução. Procurarei aqui apontar alguns deles. Não é minha intenção, claro, resolvê-los, apenas mostrar uma direção para seu possível desenvolvimento.

\subsection{Capitalismo Contemporâneo}

Que as mudanças no mundo e no país não tenham acarretado a superação da divisão de classes, da centralidade do trabalho e do capitalismo, não significa que elas não tenham ocorrido, ou tampouco que sejam de pequeno vulto. Ao contrário, não só são muitas e de grande impacto, como o resultado direto do crescimento exponencial do sistema capitalista, da centralidade do trabalho e da divisão de classes. Compreender como esta época, mais exacerbadamente voltada ao capitalismo do que qualquer outra que a precedeu, pode aos olhos de tantos se passar justamente pela superação dele, é tarefa já bem empreendida por muitos autores. Ainda assim penso que alguns aspectos deste processo devem ser apontados, por relacionarem-se mais diretamente com o objeto aqui analisado.

Primeiro, é importante notar que o crescimento e a expansão do sistema capital caracteriza-se também por uma mudança em sua forma de atuação:

"O que leva tantos a falar do 'fim da história', da pós-modernidade, da 'segunda modernidade' e da 'sobremodernidade' [...] é o fato de que o longo esforço para acelerar a velocidade do movimento chegou a seu 'limite natural'. O poder pode mover-se com a velocidade do sinal eletrônico - e assim o tempo requerido para o movimento de seus ingredientes essenciais se reduziu à instantaneidade. Em termos práticos, o poder se tornou verdadeiramente extraterritorial, não mais limitado, nem mesmo desacelerado, pela resistência do espaço [...]"[31] (Baumann, 2001:17-8; grifos do autor) 
De fato a grande diferença entre as sociedades capitalistas e as demais sempre foi a apropriação dos meios de produção pela classe dominante por meios "puramente" econômicos, dependendo em última instância da coerção física do Estado para garantir o estatuto da propriedade privada e, portanto, seu poder (O'Donnell, 1981). Sistema que deu a esta classe, já de nascença, a vantagem da desvinculação do poder oficial. Por isso, quando Baumann declara que...

"As principais técnicas do poder são agora a fuga, a astúcia, o desvio e a evitação, a efetiva rejeição de qualquer confinamento territorial, com os complicados corolários de construção e manutenção da ordem, e com a responsabilidade pelas conseqüências de tudo, bem como a necessidade de arcar com os custos." (Baumann, 2001:18)

... não faz mais do que constatar a metamorfose mais recente de uma forma de dominar que surgiu com o sistema e parece estar alcançando seu apogeu. Como conseqüência, toda a responsabilidade pela garantia efetiva dos direitos fundamentais inclusive aí o trabalho - tem sido passada adiante até mesmo por um Estado que cada vez mais abandona esse papel em favor de uma função policial, ou seja, de aguerrida defesa da propriedade.

Do outro lado, a crescente "privatização" e "individualização" da vida, onde na primeira pode-se muito bem ler "mercantilização" e, na segunda, "atomização", faz o "peso da trama dos padrões e a responsabilidade pelo fracasso" caírem "principalmente sobre os ombros dos indivíduos". A conseqüência direta é o esvaziamento da política em favor da gestão das vidas individuais, o que Baumann designa política-vida, resultando na inexistência de um espaço verdadeiramente público (Baumann, 2001) - isso é, na inexistência de uma perspectiva a partir da qual se possam interrogar abertamente os dogmas e verdades instituídos da sociedade. O esvaziamento da política é assim desaparecimento da liberdade como a entendiam os antigos: exame e deliberação comuns acerca dos destinos da coletividade.[32] No rastro segue a desorganização e fragmentação da classe trabalhadora, bem como a falsa impressão do desaparecimento da mesma (Frigotto, 1995).

Isto constitui, aliás, ponto importante: é preciso enfatizar que o acirramento do desemprego estrutural, a fragmentação da classe trabalhadora e a precarização do trabalho, não são sinais do fim do trabalho, e sim elementos fundamentais da crescente desigualdade de classes. Ao fim e ao cabo, o que caracteriza um indivíduo como membro da classe trabalhadora não é a posse de um emprego, ou mesmo de qualquer outra forma de trabalho assalariado, e sim a não-propriedade dos meios de produção, que o obriga a 
vender seu próprio trabalho para se sustentar, quer ele consiga fazê-lo ou não. A massa de desempregados, bem como a de sem-terra, sem-teto, etc; enfim a massa de excluídos, faz parte da classe dos trabalhadores.

\subsection{Imperativos de Mercado}

Entender exatamente o que é o direito ao trabalho é apenas um primeiro passo para entender como garantir sua efetivação, o que além de mais espaço e pesquisa demanda um esforço prático, político. É possível, porém, antever que, fazendo uso novamente das categorias de Mészáros, podemos pensar no exercício deste direito na relação do homem com a natureza, na relação com outros seres humanos, e na relação do homem consigo mesmo. Na primeira este exercício existe em sua acepção já comumente aceita, de proporcionar a auto-reprodução do indivíduo e a supressão de suas carências; na segunda, no sentido de que ele não dependa de outros para assegurar seu direito; na terceira, de que seu trabalho possa ser uma verdadeira externação de si, e no de viabilizar ou facilitar a fruição do mesmo. Em todos os casos esta efetivação envolve a superação do trabalho alienado.

De modo semelhante, este direito não pode ser garantido, nem ao menos em sua forma alienada, dentro de uma economia de mercado. Isto é comumente disfarçado: a própria palavra "mercado" é quase sempre associada a algum tipo de oportunidade por meio da oferta e da escolha, isto é, como sinônimo de livre iniciativa e, em última instância, de liberdade. A ideologia vigente fala a todo tempo de forças de mercado, e pouco se percebe que força significa coação, e a "característica distintiva dominante do mercado capitalista não é a oportunidade nem a escolha, mas, ao contrário, a compulsão" (Wood, 2001:16): o trabalhador é, portanto, coagido a entrar no mercado de trabalho. "O trabalhador tornou-se uma mercadoria e é uma sorte para ele conseguir chegar ao homem que se interesse por ele. E a procura, da qual a vida do trabalhador depende, depende do capricho do rico e capitalista." (Marx, 2004:24)

Logo se vê que, longe de estar livre do poder de outros seres humanos, seu direito ao trabalho depende totalmente deles. O aumento do desemprego e a crescente crise econômica só fazem colaborar para esta percepção de que ter ou não um trabalho assalariado depende muito pouco do próprio trabalhador - percepção que até nosso sistema legal começa a ter. 


\subsection{Apontamentos para a Formação de um Trabalhador e Trabalho Emancipados}

A busca por um efetivo direito, bem como de uma apropriada valorização ética do dever ao trabalho, passa pela superação do trabalho alienado, que por sua vez envolve a formação de cidadãos emancipados e, no plano mais específico, de trabalhadores emancipados. Assim, prossigo com o que imagino sejam alguns dos passos iniciais no longo caminho para o ideal da emancipação, meros apontamentos.

Penso que o primeiro e mais evidente trata destes que estão entre nossos mais cruéis e injustos dispositivos legais: as contravenções penais da vadiagem e da mendicância. Chega a ser espantoso que tais contravenções sobrevivam até mesmo ao desenvolvimento do sistema capitalista, cuja forma de funcionamento e coação "puramente econômica" pode eventualmente dispensá-las. Já a jurisprudência e a doutrina, como vimos, deram passos decisivos rumo à sua extinção; o poder legislativo já tentou anteriormente e, no momento, insiste novamente, agora por meio do Projeto de Lei $\mathrm{n}^{\circ}$ 4668/04 que, como o número indica, tramita há três anos na Câmara dos Deputados. A extinção completa destas normas repugnantes e de todos os seus vestígios é o mínimo de progresso dos direitos à liberdade e do dever ético ao trabalho que podemos buscar num futuro próximo.

Quanto à fonte de renda, tendo em vista que "todos os homens devem viver para poder fazer história", e que, dentro do sistema capitalista, como já vimos, tanto a supressão das carências quanto a própria formação do homem, dependem dela, e que a formação do trabalhador emancipado exige um trabalhador vivo e sem carências, pareceme clara a necessidade essencial da luta pelo pleno emprego. Esta, por sua vez, exige uma postura diferente dos poderes públicos quanto a sua interferência no mercado, além de diversas outras medidas econômicas (cf. Assis, 2002). Também o aumento do tempo de fruição, que tem sua manifestação mais direta na diminuição da jornada de trabalho, e como resultado provável um trabalhador menos carente de sentido, é pré-requisito para a efetivação do direito ao trabalho como externação de si e a realização da liberdade do homem para consigo mesmo. Estas duas soluções não são nem de longe definitivas, mas constituem avanços importantes e intimamente ligados, e que já são uma bandeira histórica ativamente defendida pelos movimentos sindicais, sociais, e até dentro dos organismos de Estado, por meio de projetos de lei até aqui fadados ao fracasso.

O que nos traz ao próprio Estado. Se as forças de mercado não só não garantem, como ameaçam o direito ao trabalho, o papel dele na garantia efetiva deste direito torna-se importantíssimo. Como se não bastasse, seu atual papel e formas de atuação vêm no sentido de garantir a manutenção do sistema de mercado, portanto no caminho da busca 
de todos os demais objetivos aqui relacionados. Para que todas estas bandeiras possam ser efetivamente perseguidas, então, é necessário que o papel do Estado seja reformulado, abandonando-se seu aspecto eminentemente policial; para isto, por sua vez, é imperativo que ele se transforme verdadeiramente num espaço público. Igualmente a forma de atuação do Estado na economia de mercado, terá de ser repensada, frente a este Estado reformulado. Tudo isto envolve a questão da efetivação da construção comum, e conseqüentemente a da construção de um verdadeiro diálogo democrático problemas de magnitude grande o bastante para forçar este parágrafo a um fim súbito.

Refletindo sobre estes apontamentos, temo que sejam muito Mas o jovem Marx já descobriu, tanto tempo atrás, que é na prática que as contradições da teoria se resolvem. A superação do trabalho alienado e recuperação do mesmo como mediação de primeira ordem, a garantia do direito ao trabalho e a formação do trabalhador emancipado são questões que surgem em nosso dia-a-dia, e que enfrentamos tanto como grupo quanto como individualmente: são a atitude que tomamos perante nossos semelhantes, a quem tratamos como mercadoria e de quem, como se tal fossem, cobramos o mais alto desempenho simplesmente por termos Ihes pago por isso; no valor que damos a nosso trabalho e ao de nossos pares, seja ele remunerado ou não; no juízo que fazemos daqueles que, como nós, carregam nos ombros o peso da trama dos padrões, a responsabilidade pelo próprio fracasso.

\section{REFERÊNCIAS BIBLIOGRÁFICAS:}

ISTÓTELES. Ética a Nicômaco. São Paulo: Martin Claret, 2004.

SIS, J. C. de. Trabalho Como Direito: fundamentos para uma política de promoção do no emprego no Brasil. Rio de Janeiro: Contraponto, 2002.

UMANN, Z. Modernidade Líquida. Rio de Janeiro: Jorge Zahar, 2002.

ASIL. Constituição Da República Federativa Do Brasil. São Paulo: Saraiva, 2005. 
. Lei Das Contravenções Penais. <http://www.planalto.gov.br/CCIVIL/Decreto'Del3688.htm>. Acesso: 07/05/2007.

BBIO, N. "Direitos do Homem e Sociedade". Em: Bobbio, N. A Era dos Direitos. Rio de ıeiro: Elsevier, 2004.

STORIADIS, C. "A época do conformismo generalizado", em As encruzilhadas do labirinto - A ascensão da insignificância. Rio de Janeiro: Paz e Terra, 1992.

IVATTA, M. "O conhecimento histórico e o problema teórico-metodológico das mediações", Frigotto, G. e Ciavatta, M. Teoria e Educação no Labirinto do Capital. Petrópolis: Editora 'es, 2002.

IIZ, M. H. Curso de Direito Civil Brasileiro, V. 1: Teoria Geral do Direito Civil. São Paulo: aiva, 2002.

IGOTTO, G. Educação e a Crise do Capitalismo Real. São Paulo: Cortez, 1995.

IMAN, N. "A Dream of a Thousand Cats". Em: Sandman: Dream Country. Nova lorque: DC nics, 1995.

AMSCI, A. Concepção Dialética da História. Rio de Janeiro: Civilização Brasileira, 1986.

MERO. Odisséia. São Paulo: Melhoramentos, 1967.

ZGE, H. V. N. "Vadiagem e Mendicância". <http://jus2.uol.com.br/doutrina/texto.asp? 5837>. Acesso: 07/05/2007.

SIK, K. Dialética do Concreto. Rio de Janeiro: Paz e Terra, 1976.

¿AN, J. O Seminário: livro 20: mais, ainda. Rio de Janeiro: Jorge Zahar, 1985. 
JKE, J. Ensaio acerca do entendimento humano. Rio de Janeiro: Nova Cultural, 1991 Segundo Tratado Sobre o Governo. Mimeo. . The Second Treatise of Civil Government.

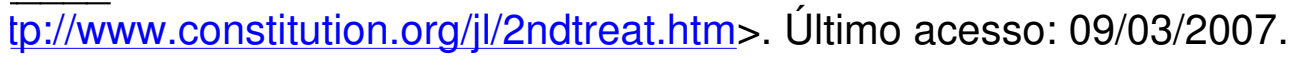

<ÁCS, G. "As Bases Ontológicas do Pensamento e da Atividade do Homem". Em: Temas Ciências Humanas. São Paulo: S. Porto, 1978.

RX, K. "Trabalho Alienado e Superação Positiva da Auto-Alienação Humana". Em: nandes, F (org.). K. Marx, F. Engels: história. São Paulo: Ática, 1983. . Manuscritos Econômico-Filosóficos. São Paulo: Boitempo, 2004. . Crítica da Filosofia do Direito de Hegel. São Paulo: Boitempo, 2005.

O Capital: Volume Um. <http://www.marxists.org/portugues/marx/1867/ocapitalndex.htm>. Acesso: 29/03/2007.

RX, K. e ENGELS, F. A Ideologia Alemã. São Paulo: Martins Fontes, 2002. . Die deutsche Ideologie. <http://www.mlwerke.de/me/me03/me03_009.htm>. ssso: $21 / 04 / 2007$.

SZÁROS, I. Marx: A Teoria da Alienação. Rio de Janeiro: Zahar, 1981.

IONNEL, G. "Anotações para uma teoria do Estado (I)". Em: Revista de Cultura e Política 3. Rio de Janeiro: Paz e Terra, 1981. 
GANIZAÇÃO DAS NAÇÕES UNIDAS. Declaração Universal dos Direitos do Homem. tp://www.unicrio.org.br/Textos/udhr.htm>. Último acesso: 07/12/06.

WELL, G. 1984. <http://www.online-literature.com/orwell/1984>. Acesso: 08/12/06.

NIERI, J. “Apresentação”. Em: Marx, K. Manuscritos Econômico-Filosóficos. São Paulo: tempo, 2004.

ALE, M. Lições Preliminares de Direito. São Paulo: Saraiva, 1998.

ZTULIAN, N. "Georg Lukács e a reconstrução da ontologia na filosofia contemporânea". fferência pronunciada na Universidade Federal do Ceará, (mimeo.), 1996.

:BER, M. A Ética Protestante e o Espírito do Capitalismo. São Paulo: Martin Claret, 2003.

JOD, E. A Origem do Capitalismo. Rio de Janeiro: Jorge Zahar, 2001.

\section{FERÊNCIAS DISCOGRÁFICAS:}

TUNES, A. e BRITTO, S. "Porrada". Em: TITÃS. 1994. C.D. Titãs 84-94. Warner Brasil, 50998895-2, Rio de Janeiro, Brasil.

2OQUATRO. "Caiu a Ficha". Em: MUNDO LIVRE S/A. 2004. C.D. O Outro Mundo de nuela Rosário. Candeeiro Records, CAN002-2, Recife, Brasil.

[1] Este artigo toma por base a dissertação de conclusão do mestrado em Políticas Públicas e Formação 
Humana do PPFH-UERJ, "O Trabalho como Direito e como Dever", orientada pelo prof. Gaudêncio Frigotto.

[2] Bacharel em Direito pela UFRJ, mestre em Políticas Públicas e Formação Humana pela UERJ.

[3] O que, vale dizer, passa pela definição do que se entende por "melhora".

[4] Ênfase no advérbio "aparentemente"; a correspondência entre uma coisa e outra será abordada mais adiante.

[5] Para mais sobre estas dificuldades, v. Ranieri, 2004:16; Mészáros, 1981:14.

[6] Sobre a distinção entre "carência" e "necessidade" como formas de manter a distinção entre os termos alemães Bedürfniss e Notwendigkeit, v. Ranieri, 2004:16-7.

[7] No presente texto, a seguinte formatação será adotada para as citações: preservam-se os parênteses da edição original; sublinham-se os grifos do autor original, enquanto para os meus usa-se o negrito; os acréscimos feitos na edição citada ao texto do autor original preservam-se por barras duplas; e por fim, acréscimos meus à citação são caracterizados pelo uso de colchetes.

[8] Neste ponto o autor originalmente ressalta novamente a definição marxista de trabalho como atividade exclusivamente humana, da qual, como já dito anteriormente, não trataremos.

[9] A versão de Ranieri é ligeiramente diferente: "Na determinação de que o trabalhador se relaciona com o produto de seu trabalho como //com// um objeto estranho estão todas estas conseqüências." (Marx, 2004:81) Chamo atenção ao grifo, em ambos os casos alegadamente do autor, porém menor na versão de Ranieri. Aqui, a tradução literal de entfremdung faz mais sentido: não é tanto o fato do produto ser alheio que importa, e sim o fato dele ser estranho a seu produtor.

[10] Há diferenças substanciais na versão de Ranieri, afora a tradução de Selbstentfremdung por "estranhamento-de-si", nos trechos: “(..)O animal se torna humano, e o humano, animal. (...) Porém na abstração que as separa da esfera restante da atividade humana, e faz delas finalidades últimas e exclusivas, são //funções// animais." (Marx, 2004:83)

[11] "Assim como ele //engendra// a sua própria produção para a sua desefetivação (Entwirklichung), para o seu castigo, assim como //engendra// o seu próprio produto para a perda, um produto não pertencente a ele, ele engendra também o domínio de quem não produz sobre a produção e sobre o produto.[...] A propriedade privada é, portanto, o produto, o resultado, a conseqüência necessária do trabalho exteriorizado, da relação externa (äusserlichen) do trabalhador com a natureza e consigo mesmo." (Marx, 2004:87)

[12] Utilizo o termo ciclo para expressar a relação de geração mútua entre liberdade e necessidade, como as concebem Mèszàros (1981) e Kosik (1976). Para este último autor "a relação entre necessidade e liberdade é uma relação historicamente condicionada e historicamente variável" (Kosik, 1976:188)

[13] A edição consultada traduz tanto Bedürfnis quanto Notwendigkeit por necessidade, sem fazer qualquer tipo de distinção, diferente das edições consultadas dos "Manuscritos". A dúvida acerca de qual necessidade estava em questão no trecho citado só pôde ser solucionada pela consulta ao texto em seu idioma original (Marx e Engels, 2007).

[14] Embora Lukács trate o trabalho como o ato livre por excelência, ele não está tratando do trabalho alienado; também vale acrescentar que a aceitação ou não desta elaboração - se o trabalho é ou não o ato livre por excelência - não é assunto direto deste artigo. Portanto, naturalmente vejo o uso destes termos com cautela.

[15] Pelo contexto da frase, fica aparente que ele refere-se à necessidade lógica, Notwendigkeit, mas nem ele nem a edição fazem qualquer esclarecimento acerca disto. Possivelmente porque a máxima aplica-se aos dois tipos de necessidade.

[16] Embora o capítulo diga respeito à teoria marxista, seria despropositado cunhar Baumann como um. Ele consta aqui porque suas palavras cabem, e porque serão retomadas mais tarde.

[17] A palavra "natural" não tem caráter de oposição ao que é "social" ou "humano"; o homem é parte 
específica da natureza (Marx, 2004:84; Mézsáros, 1981:146). De fato, não só possuem a liberdade e a necessidade existência a nível social, como, não se tratando de uma liberdade e necessidade universais e sim em um ser humano presente, não podem possuí-la fora dele. A distinção de nomenclatura é justamente para ilustrar uma aparência de distinção enganosa entre "natural" e "social".

[18] Cabe notar que esta definição, mesmo dentro de uma obra intitulada "Lições Preliminares", é também preliminar, vindo o autor a dedicar mais adiante um capítulo inteiro para chegar a uma definição mais precisa (e muito mais complexa). Para nós, porém, tal investigação seria demasiado custosa, e esta definição bastará.

[19] Como no caso, diversas outras formas de classificar direitos subjetivos têm sido invocadas. A título de exemplo poder-se-ia, digamos, falar em "direitos de ser", categoria onde residiriam os direitos de minorias ou dos incapazes - direito de ser criança, mulher, negro, homossexual, idoso, etc. Tal conceito seria, novamente, falso; embora exista no ordenamento (direito objetivo) com esta aparência, sua tradução em direitos subjetivos resulta em diversos direitos de proteção, no sentido de garantir que seus beneficiários não precisem abdicar de aspectos valiosos de sua vida (direitos de fazer) ou sejam obrigados a esforços maiores que os de seus pares (direitos de não fazer).

[20] Sobre o aspecto normativo do Direito e sua relação com os demais aspectos, ver Reale, 1998:64.

[21] "E a esse respeito direi que todo homem que tem posses ou goza de qualquer parte do domínio de um governo dá, por esse meio, consentimento tácito e está daí em diante obrigado à obediências às leis desse governo, enquanto assim goza, como qualquer outro que sob ele esteja" (Locke, II, 119). Logo retornaremos a esta relação entre o direito e o gozo.

[22] Para mais sobre isto, naturalmente, ver Weber, 2003.

[23] Já em Homero, como em outros clássicos, podemos ver como a mendicância, embora motivo de vergonha, era tolerada, e o homem justo devia tratar bem aos estrangeiros e mendigos, dando-lhes hospedagem e esmolas. "Leva isto tudo para o hóspede, caro, e lhe dize que pode/ os pretendentes, depois, procurar, para esmola pedir-Ihes,/ pois a vergonha é ruim companheira de quem necessita." (Odisséia, XVII, 346-8. Ver também o canto VI e o restante do XVII.)

[24] 0 que não raro leva à violência institucionalizada: "Medalhinhas para o Presidente/ Condecorações aos veteranos/ Reivindicações para os bancários/ Congratulações para os banqueiros/ Porrada!/ Pros caras que não fazem nada" (Antunes e Brito, 1994)

[25] Se podem ser parte do mundo da necessidade, porém, é questão mais abrangente, que não cabe aqui tentar resolver.

[26] Note-se que os interesses particulares não podem, como um todo, suplantar o fim do Estado, justamente porque são muitos e divergentes entre si. Mas um único interesse ou grupo de interesses pode perfeitamente bem suplantar o fim do Estado, usando-o de acordo com seus propósitos (o que constantemente ocorre), e gerando o cenário recorrente onde um particular dita as finalidades do Estado, que por sua vez as impõe a todos os demais interesses particulares.

[27] Importante relembrar que ele só o faz após longa análise da economia política, que naturalmente não é de nosso interesse refazer.

[28] Autonomia esta reafirmada pelos economistas. Por isto: "A economia nacional [política] parte do fato dado e acabado da propriedade privada. Não nos explica o mesmo." (Marx 2004:79)

[29] Novamente: "Porrada!/ Pros caras que não fazem nada".

[30] Sobre as diferenças entre a teleologia e a causalidade, v. Tertulian, 1996, e outros.

[31] "Virtual, inaudível / voa certeiro, / sorrateiro/ rápido e mortal / não existe guerra alguma, / apesar de todo $€$ 
[32] Note-se que Baumann está declaradamente seguindo o raciocínio de Castoriadis, a partir da idéia de que o mal de nossa sociedade é ter deixado de questionar-se. Cf. Castoriadis, 1992.

volta

file://C:WDocuments and Settings\Administrador\Meus documentos\Minhas Webs\NED... 11/9/2008 